\title{
The Role of Competition Law: An Asian Perspective
}

\author{
Rita Yi Man $\mathrm{Li}^{1} \&$ Yi Lut $\mathrm{Li}^{2}$ \\ ${ }^{1}$ Department of Economics and Finance, Hong Kong Shue Yan University, Hong Kong \\ ${ }^{2}$ School of Law, City University of Hong Kong, Hong Kong \\ Correspondence: Rita Yi Man Li, Department of Economics and Finance, Hong Kong Shue Yan University, \\ Hong Kong. Tel: 852-2570-7110. E-mail: ritarec1@yahoo.com.hk
}

Received: March 4, 2013 Accepted: April 8, 2013 Online Published: June 1, 2013

doi:10.5539/ass.v9n7p47 URL: http://dx.doi.org/10.5539/ass.v9n7p47

\begin{abstract}
In EU and the US, competition law regulates the practices of large firms so as to protect consumer welfare and economic efficiency. In Asia, many countries such as China and Vietnam are shifting to market economy; small firms expand and grow to become large scale corporations. Competition law is gaining importance in these countries. This paper firstly provides an overview on the role of the competition law in protecting consumer efficiency and consumer welfare. Afterwards, content analysis on the previous journal articles about Asia's countries competition law, such as China, Vietnam, South Korea, Japan, India will be conducted. Lastly, a case study on supermarket in Hong Kong shows the role of competition law.
\end{abstract}

Keywords: competition law, antitrust law, consumer welfare, economic efficiency, content analysis, case study, Asia, Hong Kong

\section{Introduction}

Over the past few years, economic development and the gradual shift from government planned economy in many places lead to a chorus of voices has called for action in the arena of competition policy (Aydin, 2012; Tarullo, 2000). Competition law (also known as antitrust law in the US) is often used to protect the competition process in the market by installing a legal framework to regulate the practices of undertakings (Parakkal, 2011; Isac \& Elena, 2010; Simpson, 2010) and provides a good environment for business entities (Jashari \& Memeti 2012). It has become increasingly popular in various economies to embrace the market mechanism (Wu, 2012). Scholarly speaking, by facilitating competition, competition law is designed to achieve efficient allocation of resources; enhances consumer welfare by lowering product price, quality and services (Roberts, 1996); and provides innovation incentive (Iacobucci et al., 2006; Hooper \& Price, 2010).

\section{An Overview on the Roles of Competition Law in EU and the US}

Generally speaking, economists regard the promotion and protection of competition process as the most important direction in the understanding of competition law. Roberts asserted that competition is the best means to allocate resources and in turn provide consumers with more alternatives (Roberts, 1996). Gal (2004) concluded that the major goal is to limit the abuses of monopoly power by dominant firms. Jens and Stephan pointed out that such law is implemented against the limitation of competition or unfair competition and set the level of playing field for the market system. It is drafted to protect the smaller firms from the power of the larger enterprises (Calvani, 1981; Lapachi \& Ketevan, 2002). In Intel case law, it was found that political considerations played more important role than economic reasoning behind the EU antitrust decision (Mazzone \& Mingardi, 2011). Tackling of monopolistic pricing is also a main concern (Wu, 2012). All in all, as Kirkwood et. al. (2008) commented, promotion of consumer welfare is not the first priority in implementation of competition law.

\subsection{Competition Law's Role in Efficient Allocation of Resources and Consumer Welfare}

Nevertheless, Baarsma (2011) and Kerber (2007) held opposite view. Competition law is aimed at promoting consumer welfare. The relationship between efficient allocation of resources and competition is generalized by the theory of welfare economics. Under perfect competition, Pareto-efficiency of allocation will be fulfilled without the presence of state intervention (Kerber, 2007). This is achieved ay the equilibrium prices, say $\mathrm{P}^{*}$, where the market demand and supply curves intersect. Consumer surplus is the difference between the price that 
a consumer is willing to pay at each unit (indicated as along demand curve PC) and the price that he actually pays, i.e. $\mathrm{P}^{*}$. Accordingly the total consumer surplus for quantity transacted at $\mathrm{Q}^{*}$ (equilibrium quantity) as represented by triangle $\mathrm{AP}^{*} \mathrm{C}$. Nonetheless, efficient allocation of resources shall be the summation of consumer and producer surplus in perspective of economics; where producer surplus refers to the difference between the price paid by the consumer $\left(\mathrm{P}^{*}\right)$ and the minimum sum of money received by the producer such that he is willing to produce (indicated as along supply curve EC), graphically presented as area $\mathrm{P}^{*} \mathrm{EC} \square$.

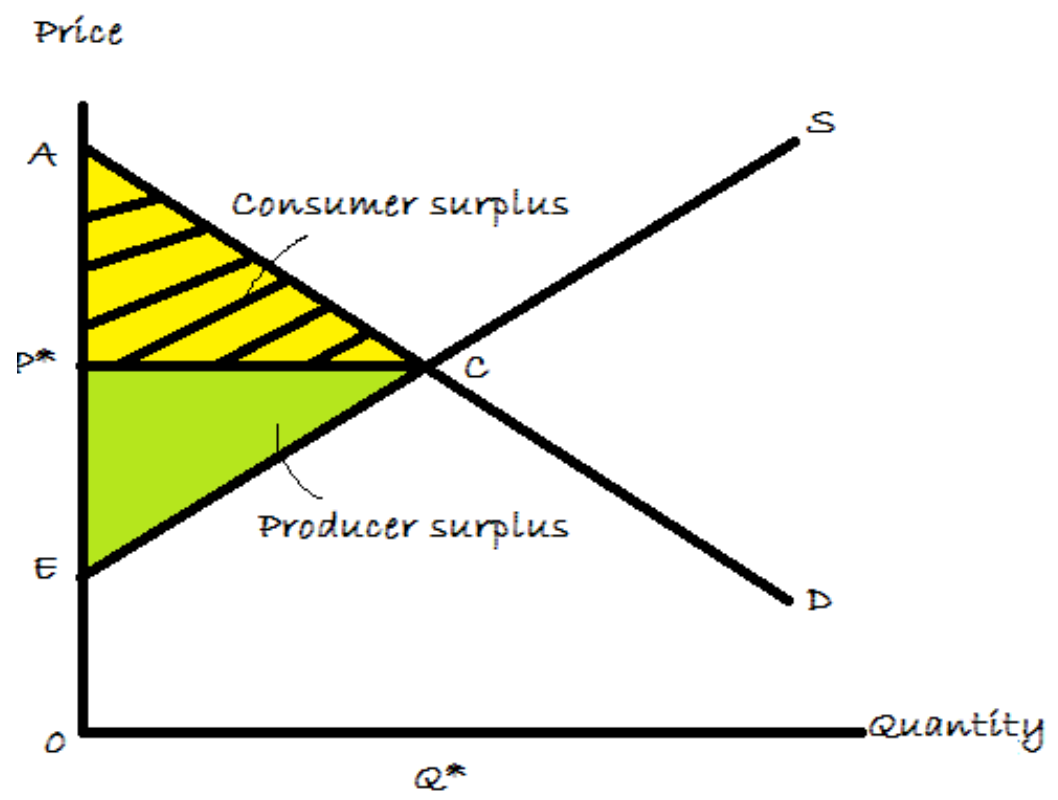

Figure 1. Perfect competition

Besides, as concluded by Brodley, consumer welfare shall be referred to as the "direct and immediate welfare of the consumers of a distinct product" (Brodley, 1987). The end result of implementing competition law is to enhance the economic efficiency where consumer shall obtain an appropriate share of such welfare, i.e. consumer welfare. In the language of economics, consumer welfare is thus defined as consumer surplus (Brodley, 1987). In other words,

1). consumer welfare $=$ consumer surplus;

2).efficient allocation of resources $=$ consumer surplus + producer surplus

Accordingly, consumer surplus is not the same as efficient allocation, but is part of it.

\subsection{How Does Competition Law Help Achieve More Efficient Allocation of Resources \& Consumer Welfare?}

In absence of competition law, small stand-alone stores will be replaced by vertical marketing systems which are professionally managed and centrally programmed networks, designed to achieve managerial, promotional, technological economies through the synchronization, integration and co-ordination and the marketing flows from production to ultimate use (Baily \& Gordon, 1993). The continuous expansion may ultimately end up with one single large monopoly firm. The successful rival, however, produces up to the quantity where marginal revenue that it could earn for that unit is the same as marginal cost of production, i.e. Qm. At that quantity, the price is raised to Pm and quantity transacted is lowered to Qm. At that point, the consumer surplus and producer surplus are reduced to $\mathrm{APmB}$ and EPmBD respectively. As compared to perfect competition where efficient solution is obtained at the intersection of the demand and supply curve, a deadweight loss as indicated by BCD is resulted (Brue et al., 2010). 


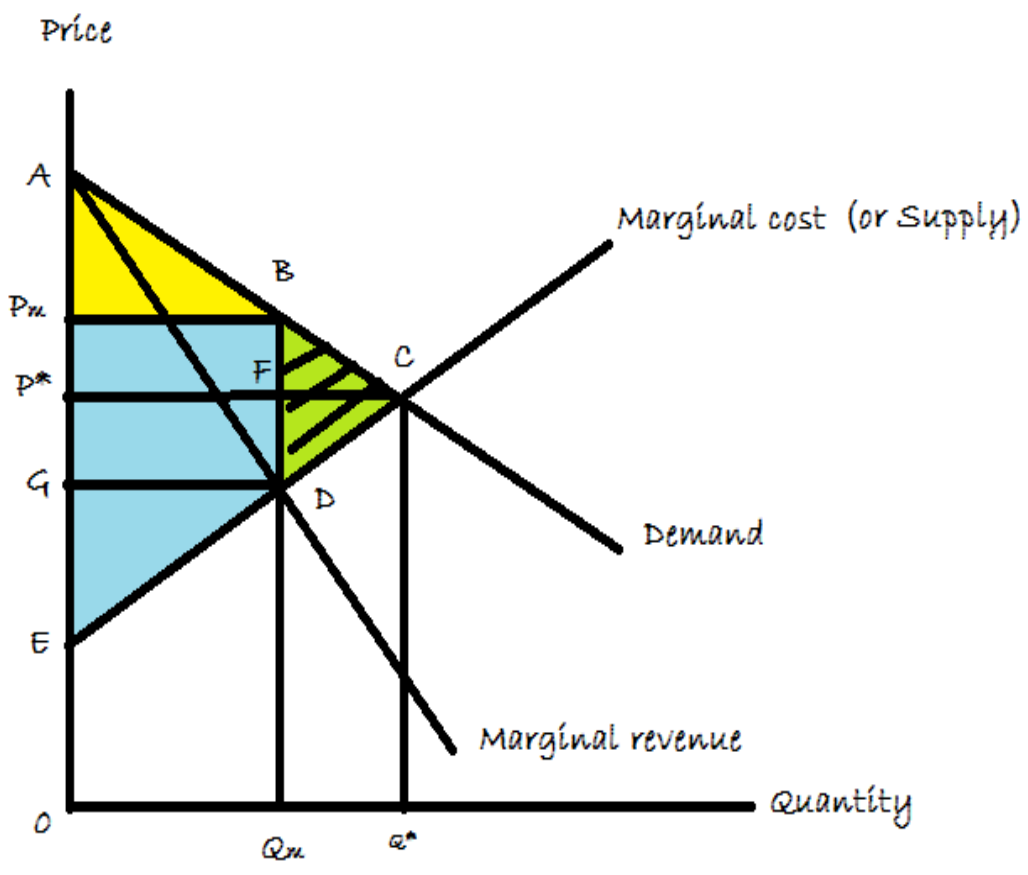

Figure 2. Monopoly

Table 1. Comparison between perfect competition \& monopoly (Brue et. al. 2010)

\begin{tabular}{lll}
\hline & Perfect competition & Monopoly \\
\hline Price & $\mathrm{P}^{*}$ & $\mathrm{Pm}$ \\
Quantity & $\mathrm{Q}^{*}$ & Qm \\
Marginal revenue & It is equal to demand schedule & $\begin{array}{l}\text { Marginal revenue curve falls below } \\
\text { the demand curve if the sellers } \\
\text { want to sell one more units, they do }\end{array}$ \\
& & $\begin{array}{l}\text { not only need to lower the price of } \\
\text { one unit but all the previous units }\end{array}$ \\
Most efficient point & Marginal revenue = marginal costs & \\
Consumer surplus & ACP & ApmB \\
Producer surplus & $\mathrm{P}^{*} \mathrm{CE}$ & $\mathrm{EPmBD}$ \\
Deadweight lose & No & BCD \\
\hline
\end{tabular}

Asserted by the scholars, one of the aims of implementing competition law is to prevent the expansion of company which eventually ends up with one single monopoly where total surplus of a society reduces (Parakkal, 2011). Pursuant thereto, competition law could be said as a legal tool which "guide" the market structure move to the perfect competition situation (Figure 1) and move away from the monopoly market structure (Figure 2). Accordingly, consumer welfare could be enlarged with the help of competition law (Leslie, 2009) and allocation of resources is more efficient (Figure 1 and Table 2).

\section{Research Method}

There are two major qualitative research methods in this research. The first one is content analysis on the journal articles which studies the reasons on the rationale of the provision of the competition law and the second part is a case study on Hong Kong's supermarket.

As mentioned in Chang et. al. (2013), content analysis is used to investigate and describe the data by extracting and evaluating the occurrences of the latent content of a body of textual material in a systematic way. An appropriate content classification scheme is an important step. Similar to any other qualitative research method, 
content analysis has its weaknesses and strengths. To successfully develop content analysis, classification and measurement of data must be undertaken with objectivity, rigor and exactness which requires a large degree of personal judgment and requires an in-depth knowledge on the subject matter. After that, a case study on Hong Kong Supermarket (Welcome, Park'n Shop and 759) case study enables us to obtain in-depth information from detailed descriptions of events and observed behaviors ( $\mathrm{Li}, 2013 \mathrm{~b}$ ) on the rational of competition law.

\section{The Role of Competition Law in Asia: A Literature Review}

Similar to many other places around the globe, competition law is designed to protect economic efficiency (Owen et al., 2008; Poapongsakorn, 2002; Huang et al., 2010) and consumer welfare (Owen et al., 2008; Poapongsakorn, 2002); prohibit or prevent the existence of monopolistic behaviour/mergers (Harris, 2006; Sun, 2011); promotes competition (Luu, 2012; Patel, 2011; Porter \& Sakakibara, 2004; Sun, 2011; Yun \& Hong, 2005) and unscrupulous business practices (Ho \& Chan, 2003; Clarke, 2011). In Korea, Shin (2002) suggested that the existence of the competition law in Korea is to prevent the special form of conglomerates. Similar line of reasoning can also be found in Japan (Suzuki, 2002). As many of the countries in Asia are developing countries, apart from the abovementioned reasons which are very common in EU or the US, the implementation of competition laws in Asia countries are also considered as a tool which can stimulate economic growth, example India (Patel, 2011); international integration in Vietnam (Doan \& Stevens, 2012) and promote fairness in Asia (Liu, 2012), China (Huang, et. al. 2010) and Indonesia (Pangestu et al., 2002) and solve some of the problems which are common in developing countries such as the problem of the lack of effective institutions and regulations in Indonesia (Pangestu et al., 2002) and monetary problems in Israeli (Gal, 2004).

Table 2. Major purpose of implementing competition laws (author's research)

\begin{tabular}{|c|c|c|}
\hline Author & Country & The major purpose of implementation of competition law \\
\hline Luu (2012) & ASEAN & Competition law nurtures the competitive environment in an economy. \\
\hline Liu (2012) & Asia & It aims at ensuring fairness. \\
\hline Clarke (2011) & $\begin{array}{l}\text { Central } \\
\text { Asia* }\end{array}$ & $\begin{array}{l}\text { Competition laws prevent firms in the same industry from forming cartels or } \\
\text { colluding, prevent dominant firms from exercising market power; mandatorily } \\
\text { require firms to notify the competition agency about mergers and allow the officials } \\
\text { to investigate and prohibit mergers. }\end{array}$ \\
\hline
\end{tabular}

Harris, H. S. China This law aims to prohibit monopolistic behaviour, protect and promote market (2006) competition, ensure the healthy development of the socialist market economy, safeguard the legitimate rights, consumers and public interests.

Huang, et. al. China It promotes the healthy development of China's socialist market economy, enhances (2010) economic efficiency, prevents and restrains monopolistic conduct, protects fair competition in the market, safeguard consumers' and the public's interests.

Owen, et. al. China Antitrust law seeks to protect customers and businesses, prevent the wealth transfers (2008) due to the creation and exercise of undue market power. Making sure that goods are made by the firm that can produce them at lowest cost, and that goods flow to those consumers who value the goods the most, it promotes economic efficiency. Finally, it seeks to promote private competitive markets as alternatives to regulated monopolies or state-owned enterprises.

Sun (2011) China Anti-monopoly law aims to protect market competition, i.e. rival's competitive rights as well as consumers' interests.

Sun (2011) China It promotes the transformation and development of economic system, challenges the existing monopolies of domestic companies and promotes market competition.

Ho \& Chan Hong It gives consumers' the right to full redress against unscrupulous business practices. (2003) Kong Patel (2011) India

Competition law promotes competition, economic growth and innovation. It prevents certain behaviors which may restrict competition. It also promotes consumer welfare by maintaining the qualities of the goods in the market and new products to the market. It also aims at preventing unfair trade practices, curbing the abuse of monopoly power in the market.

Pangestu, et. al. Indonesia It protects consumers and ensure fair competition, solves the problem of the lack of (2002) effective institutions and regulations, ensures market mechanisms worked for efficiency outcomes. 


\begin{tabular}{|c|c|c|}
\hline Author & Country & The major purpose of implementation of competition law \\
\hline Gal (2004) & Israeli & $\begin{array}{l}\text { The Israeli competition act tries to create an e } \\
\text { small and developing economy while combats n }\end{array}$ \\
\hline $\begin{array}{lr}\text { Porter } \quad \& \\
\text { Sakakibara, } 2004\end{array}$ & $\begin{array}{l}\text { \& Japan } \\
4\end{array}$ & $\begin{array}{l}\text { The goal of the law is to break up the "zaibatsu", which are obstacles to competition } \\
\text { and democratization in Japan. }\end{array}$ \\
\hline Suzuki (2002) & Japan & $\begin{array}{l}\text { The purpose of the Anti-Monopoly Act is to prevent the emergence of large-scale } \\
\text { conglomerates. }\end{array}$ \\
\hline Shin (2002) & Korea & $\begin{array}{l}\text { Competition law includes direct controls on chaebols (a special form of business } \\
\text { conglomerates in South Korea). Nevertheless, it was found to be ineffective in } \\
\text { resolving chaebol-related problems because of the insufficient attention having been } \\
\text { paid to the problems of market power. }\end{array}$ \\
\hline $\begin{array}{l}\text { Yun \& } \\
(2005)\end{array}$ & g $\mathrm{F}$ & $\begin{array}{l}\text { It prohibits mergers achieved through coercion or any other unfair methods, } \\
\text { restricting competition in a trade. It also enhances efficiency which results from a } \\
\text { merger in terms of research and development, production, sales. }\end{array}$ \\
\hline $\begin{array}{l}\text { Poapongsakorn } \\
(2002)\end{array}$ & Thailand & $\begin{array}{l}\text { It aims to enhance the competitive process by improving the enforcement } \\
\text { mechanism. It also protects consumer with administrative measures and prevents } \\
\text { rapid growth in the prices of services and goods, competition and competitive } \\
\text { process. It also promotes economic efficiency, maximizes social welfare, promotes } \\
\text { the competitive process and prevents monopolistic behaviors which include price } \\
\text { fixing and bid rigging. }\end{array}$ \\
\hline $\begin{array}{l}\text { Doan \& Stevens } \\
(2012)\end{array}$ & s Vie & $\begin{array}{l}\text { The introduction of various laws which include Competition Law in } 2005 \text {, increase } \\
\text { international integration and stimulate competition. The improvement in competition } \\
\text { also leads to a massive growth in number of firms. }\end{array}$ \\
\hline
\end{tabular}

*The study also includes Europe.

\section{The Role of Competition Law in Hong Kong: A Review on Supermarkets}

In Hong Kong, there are two large scale supermarkets: Welcome (278 shops) and Park'n Shop (there are 263 shops altogether with 8 different branch names: 163 Park'n Store, 10 Taste, 7 Fusion, 1 Gourmet, 1 Great, 47 Superstore, 4 Express, 24 International, 6 Park'n Shop Frozen Food Store). In 2011, the Swire Company in Hong Kong forced the 759 Snack Shop to set a higher price for Coca Cola. Although the 759 Shop followed, Swire finally stopped selling all the Coca Cola to 759 snack shop. Without the supply from Swire, 759 Snack Shop could not sell any Coca Cola to their customers. There was rumor that the two chained store, Welcome and Park'n gave much pressure to the Coca Cola supplier, Swire (Apple Daily, 2011). This also led to a hot topic in Hong Kong on the issue; politicians and the lawmakers urged the government to quicken the process of implementing competition law. In fact, prior to 759, many Hong Kong people have already noticed that the number of traditional grocery stores decreases substantially. As small scale sellers buy relatively small quantity of goods, suppliers cannot offer a favorable low bulk purchase wholesale price for the goods. Sometimes, large scale Park'n and Welcome sell some goods even at a lower price than the grocery sellers' suppliers' wholesale price. In view of the slim profit, many of these small shops close.

The Chinese culture emphasizes the protection of the poorer. A Chinese proverb even says, "Rob the unethical rich to relieve the poor." (Jie-fu-ji-pin) Taking the case of supermarket as an example, the reason why the "coca-cola incident" arose the public concern could be explained in the sense that the public are dissatisfied by the supermarket duopoly's misuse of their market power. Meanwhile, the lawmakers in Hong Kong fundamentally are nurtured with the traditional idea to protect the poor, i.e. citizens and the small enterprises. Besides, as they are elected by the public, they must not deviate from the general public's view points. We can conclude that competition law in lawmakers' eyes is first to protect the consumer welfare and second to the small scale-entrepreneurship. One can conclude that efficient allocation is not the focal point of the legislation.

\section{Conclusion}

Competition law is delegated to protect the competition process and curb the emergence of monopoly created by misuse of market power of big undertakings. Economists mainly lean on the suggestion of promoting efficiency. Nonetheless, lawmakers -- the most influential group in promoting legal implementation -- would treat competition regulations as a tool to mainly protect the consumer welfare. Suffice to conclude that the lawmakers' view determines the primary goal of competition law. 


\section{References}

Apple Daily. (2011). 759 was Forced to Increase the Selling Price from $\$ 2.7$ to $\$ 3.8$ and Stopped the supply of Coca Cola' dated Oct 27, 2011. Retrieved July 19, 2012, from http://hk.apple.nextmedia.com/news/art/20111027/15745056

Aydin, U. (2012). Between Domestic Factors and the EU: Explaining the Emergence of the Turkish Competition Regime. The Antitrust Bulletin, 57(2), 303-335.

Baarsma, B. E. (2011). Rewriting European Competition Law from an Economic Perspective. European Competition Journal, 7(3), 559-585.

Baily, M. N., \& Gordon, R. J. (1993). Competition, Regulation, and Efficiency in Service Industries. Brookings Papers on Economic Activity, 2, 71-130

Brodley, J. F. (1987). The Economic goals of antitrust: Efficiency, Consumer Welfare and Technological Process. New York University Law Review, 62, 1020-1053.

Brue, S. L., McConnell, C. R., \& Flynn, S. M. (2010). Essentials of Economics. McGraw Hill.

Calvani, T. (1981). The Mushrooming Brunwick Defense: Injury to Competition, Not to Plaintiff. Antitrust Law Journal, 50, 319-345.

Chang, Y. M., Bair, H., \& Pai, J. Y. (2013). The Changing Image of Physician in Taiwan. Asian Social Science, 9(4), 32-41. http://dx.doi.org/10.5539/ass.v9n4p32

Clarke, G. R. G. (2011). Competition Policy and Innovation in Developing Countries: Empirical Evidence. International Journal of Economics and Finance, 3(3), 38-49.

Doan, T., \& Stevens, P. (2012). Evolution of Competition in Vietnam Industries over the Recent Economic Transition. Economics: The Open-Access, Open-Assessment E-Journal, 6(19), 2012-2019.

Gal, M. S. (2004). The Ecology of Antitrust Preconditions for Competition Law Enforcement in Developing Countries. In Competition, Competitiveness Development. UNCTAD.

Harris, H. S. (2006). The Making of an Antitrust Law: The Pending Anti-Monopoly Law of the People's Republic of China. Chicago Journal of International Law, 7(1), 169-229.

Ho, S. C., \& Chan, C. F. (2003). In Search of a Competition Policy in a Competitive Economy: The Case of Hong Kong. The Journal of Consumer Affairs, 37(1), 68-85. http://dx.doi.org/10.1111/j.1745-6606.2003.tb00440.x

Holscher, J., \& Stephan, J. (2004). Competition Policy in Central Eastern Europe in the Light of EU Accession. Journal of Common Market Studies, 42, 321-345. http://dx.doi.org/10.1111/j.1468-5965.2004.00490.x

Hooper and Catherine Waddams Price. (2010). Innovation and Competition in Generation and Retail Power Markets. Economic Affairs, 30(2), 13-20. http://dx.doi.org/10.1111/j.1468-0270.2010.01999.x

Huang, Y., Jiang, S., Moss, D., \& Stutz, R. (2010). China's 2007 Anti Monopoly Law: Competition and the Chinese Petroluem Industry. Energy Law Journal, 31(2), 337-370.

Iacobucci, E., Trebilcock, M., \& Winter, R. A. (2006) The Canadian Experience With Deregulation. University of Toronto Law Journal, 56, 1-74. http://dx.doi.org/10.1353/tlj.2006.0001

Isac, E. (2010). Economic and Legal Aspects of the Planned Damages Actions for Breaches of EC Antitrust Law. Romanian Journal of European Affairs, 10(3), 16-29.

Jashari, A., \& Memeti, N. (2012). Competition Law in Macedonia: Am Important Factor for Economic Development. International Journal of Business, Humanities and Technology, 2(3), 105-111.

Kerber, W. (2007). Should Competition law promote efficiency? Some Reflections of an economist on the normative foundations of competition law'. In Economic (pp. 3-4). Edward Elgar Publishing.

Kirkwood, J. B., \& Robert, H. (2008). The Fundamental Goal of Antitrust: Protecting Consumers, Not Increasing Efficiency. Notre Dame Law Review, 83, 191-244.

Lapachi, K. (2002). An examination of the present competition law of Georgia using Pittman's criteria. Antitrust Bulletin, 47(1), 187-215.

Leslie, C. R. (2009), Antitrust and Patent Law as Component Parts of Innovation Policy. Journal of Corporation Law, 34(4), 1259-1289. 
Li, R. Y. M. (2013). Knowledge Management, Sharing and Creation in Developing Countries' Banking Industries. Advances in Network and Communications, 1(1), 13-26.

Li, R. Y. M., \& Poon, S. W. (Eds.). (2013). Case Studies on Safety Measures Implementation in Construction Safety. Germany, Springer. http://dx.doi.org/10.1007/978-3-642-35046-7

Liu, L. S. (2012). All about Fair Trade?--Competition Law in Taiwan and East Asian Economic Development. Antitrust Bulletin, 57(2), 259-301.

Luu, H. L. (2012). Regional Harmonization of Competition Law and Policy: An ASEAN Approach. Asian Journal of International Law, 2(2), 291-321. http://dx.doi.org/10.1017/S2044251312000124

Mazzone, L., \& Mingardi, A. (2011). Innovation, Competition and Antitrust: an Examination of the Intel Case. Economic Affairs, 31(2), 69-75. http://dx.doi.org/10.1111/j.1468-0270.2011.02083.x

Owen, B. M., Sun, S., \& Zheng, W. (2008). China's Competition Policy Reforms: the Anti-monopoly Law and Beyond. Antitrust Law Journal, 75(1), 231-265.

Pangestu, M., Aswicahyono, H., Titak, A., \& Ardyanto, D. (2002). The Evolution of Competition Policy in Indonesia. Review of Industrial Organization, 21(2), 205-224. http://dx.doi.org/10.1023/A:1019633829374

Parakkal, R. (2011). Political characteristics and competition law enactment: A cross-country empirical analysis. The Antitrust bulletin, 56, 609-629.

Patel, A., Panda, A., Deo, A., Khettry, S., \& Mathew, S. P. (2011). Intellectual Property Law \& Competition Law. Journal of International Commercial Law and Technology, 6(2), 120-130.

Poapongsakorn, N. (2002). The New Competition Law in Thailand: Lessons for Institution Building. Review of Industrial Organization, 21(2), 185-204. http://dx.doi.org/10.1023/A:1019681612535

Porter, M. E., \& Sakakibara, M. (2004). Competition in Japan. The Journal of Economic Perspectives, 18(1), 27-50. http://dx.doi.org/10.1257/089533004773563421

Roberts, G. R. (1996). The NCAA, Antitrust, and Consumer Welfare. Tulane Law Review, 70, 2631-2674.

Shin, K. (2002). The Treatment of Market Power in Korea. Review of Industrial Organization, 21(2), 113-128. http://dx.doi.org/10.1023/A:1019617325739

Simpson, B. P. (2010). Two Theories of Monopoly and Competition: Implications and Applications. The Journal of Applied Business and Economics, 7(4), 139-151.

Sun, J. (2011) The implementation of China's anti-monopoly law: A case on Coca-Cola's abortive acquisition of Huiyuan Juice. Frontiers of Law in China, 6(1), 117-130. http://dx.doi.org/10.1007/s11463-011-0120-x

Suzuki, K. (2002). Japanese Competition Policy in the 1990s: Remaining Uniqueness in the Policy Network. Asian Business \& Management, 1(3), 313-328. http://dx.doi.org/10.1057/palgrave.abm.9200022

Tarullo, D. K. (2000). Norms and Institutions in Global Competition Policy. The American Journal of International Law, 94, 478-504. http://dx.doi.org/10.2307/2555320

Wu, Q. (2012). EU-China Competition Dialogue: A New Step in the Internationalisation of EU Competition Law? European Law Journal, 18, 461-477. http://dx.doi.org/10.1111/j.1468-0386.2012.00608.x

Yu, S. R., \& Hong, D. S. (2005). Merger Regulations under the Korean Competition Law. Journal of Korean Law, $4(2), 103-137$.

\section{Copyrights}

Copyright for this article is retained by the author(s), with first publication rights granted to the journal.

This is an open-access article distributed under the terms and conditions of the Creative Commons Attribution license (http://creativecommons.org/licenses/by/3.0/). 